Copyright (C) 2021 by Cherkas Global University

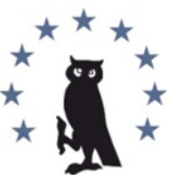

Published in the USA

Russkii Arkhiv

Has been issued since 1863 .

E-ISSN: 2413-726X

2021. 9(2): 224-231

DOI: $10.13187 /$ ra.2021.2.224

https://ra.cherkasgu.press

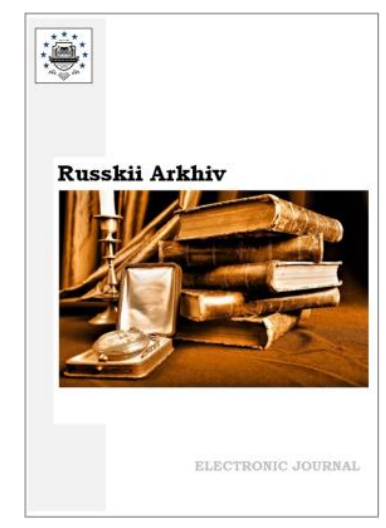

\title{
Memoirs of a Participant in the Restoration of the Ascension Church of the Khutor Susat in the Rostov Region in the 1980 s
}

Preparation for publication, introductory article and comments

\author{
Alla V. Shadrina ${ }^{a}$ * $^{*}$ \\ a Federal Research Centre the Southern Scientific Centre of the Russian Academy of Sciences, \\ Russian Federation
}

\section{Abstract}

One of the least studied aspects of the life of society in the late Soviet and early post-Soviet periods is the time of the so-called "religious renaissance", which was characterized both by an increased interest in religion and the Russian Orthodox Church, and by the return of churches to the everyday life of Russians. The handing over of dilapidated churches to believers became the reason for the beginning of the frequently long termed restoration processes. The published document, which is the memoirs of a participant in the restoration of the church in the khutor Susat of the Semikarakorsky district of the Rostov region, gives an idea of the unique and unparalleled in the south of Russia cases of the restoration of the church with the help of local authorities and large enterprises of the Semikarakorsky district of the Rostov region. The published source is a manuscript created in 2008 at the request of the dean of the Ascension Church, priest V. Minaev, who collected materials for writing a book on the history of temples in the khutor Susat.

Keywords: autocommunicative source, late Soviet period, Rostov region, khutor Susat, reconstruction of the church.

В 1980-х гг. важной тенденцией развития советского общества стало неожиданное возвращение религии, которая по инициативе атеистического государства сознательно и методично уничтожалась на протяжении 1960-1970-х гг. Следствиями этого процесса стало закрытие и разрушение в период хрущевской «оттепели» значительного числа церквей, дискредитация верующих за счет организованного местными органами власти выступления священников-ренегатов. Политические трансформации конца 1980-х гг. поставили вопрос о возможности передачи верующим храмов, использовавшихся по усмотрению местной власти в качестве складских помещений, спортзалов и др., и их реставрации. Если вопрос о передаче остатков церковных сооружений массово организующимся группам верующих в конце 1980-х гг. в подавляющем большинстве случаев решался положительно, то проблема восстановления полуразрушенных храмовых сооружений вызывала большие сложности, во многих случаях не решенных до настоящего времени. В связи с этим, опыт восстановления Вознесенской церкви в хуторе Сусат Ростовской области уникален, поскольку демонстрирует сотрудничество на тот момент еще

\footnotetext{
${ }^{*}$ Corresponding author

E-mail addresses: shadrina@ssc-ras.ru (A.V. Shadrina)
} 
советских местных органов власти и приходского священника, а обращение к такому автокоммуникативному источнику, как воспоминания участника этого процесса, представляется актуальным.

Изменение отношения к религии в советском обществе 1980-х гг. и связанная с ним реставрация церквей отражены в изданиях, посвященных истории отдельных храмов. В Ростовской области на протяжении последних 20 лет было опубликовано только 4 таких исследования, в которых рассматриваются истории церквей г. Константиновска Ростовской области (Шадрина, 2012), с. Николаевка (Молчанова, Макаренко, 2020) и с. Лакедемоновка Неклиновского района Ростовской области (Кравченко, Маврикий (Звягинцев), Федорова, Андрющенко, 2020), а также ростовского кафедрального собора Рождества Пресвятой Богородицы (Шадрина, 2021). Во всех изданиях зафиксировано, что процесс реставрации был возложен исключительно на приход и длился на протяжении многих лет. Так, например, ростовский кафедральный собор был отреставрирован после завершения советского периода только в 2019 г.

Автокоммуникативные источники, посвященные реставрации приходских храмов в поздний советский период, до настоящего времени не публиковались, что обусловлено главным образом нежеланием участников восстановления церквей фиксировать собственные воспоминания и подчеркивать свою роль в происходивших событиях, что не в последнюю очередь объясняется устоявшимся в советское время страхом наказания.

Публикуемый источник, представляющий собой воспоминания участника восстановления церкви в хуторе Сусат Семикаракорского района Ростовской области, зафиксированные им лично в письменном виде, важен как свидетельство процессов, характерных для 1980-х гг. Несмотря на идеологические предпочтения, как руководства региона, так и жителей хутора Сусат, в 1980-х гг. при первой же возможности местные жители, вошедшие в состав церковной двадцатки, зарегистрировали у уполномоченного по Ростовской области действовавшего до 1991 г. Совета по делам религий, общину Вознесенской церкви. Также они смогли получить для возобновления богослужений полуразрушенное здание храма. Назначенный епархиальным архиереем в качестве его настоятеля молодой священник и его отец взяли на себя инициативу обращения за помощью к представителям местных органов власти и крупнейших предприятий Семикаракорского района Ростовской области. Взаимодействие этих чиновников и представителя Русской православной церкви, невозможное еще в начале 1980-х гг., увенчалось воссозданием здания церкви, что представляло собой прецедент, не имевший аналогов не только в Ростовской области, но и на юге России.

Для понимания выполненного объема работ по реставрации храма необходимо обратиться к краткой истории Вознесенской церкви. Ходатайства о постройке каменной церкви в хуторе Сусатском (с 1920-х гг. хуторе Сусат) Области войска Донского начались 31 декабря 1910 г. в связи с тем, что деревянная церковь того же хутора во имя иконы «Всех скорбящих Радость» сгорела (ГАРО. Ф. 301. Оп. 25. Д. 422. Л. 292). Как правило, именно эта причина в большинстве случаев была поводом для строительства каменной церкви и учреждения нового прихода. Несмотря на отсутствие средств, что было зафиксировано в архивных документах, в 1913 г. каменный храм был возведен, а в январе 1914 г. освящен его центральный престол во имя Вознесения Господня (ГАРО. Ф. 226. Оп. 5. Д. 667. Л. 1). В советский период первый раз храм был закрыт в 1929 г. (Табунщикова, Шадрина, 2013: 199). На протяжении 1930 г. верующие обращались во все возможные советские инстанции с жалобами на незаконное закрытие. В результате, 8 мая 1930 г. на заседании бюро Президиума областного исполнительного комитета было принято решение об открытии церкви в хуторе Сусат (Табунщикова, Шадрина, 2013: 252), которая действовала до 1938 г. (Табунщикова, Шадрина, 2013: 387). После закрытия Вознесенской церкви до 1980-х гг. храм использовался как складское помещение. Как писал в 2008 г. по просьбе настоятеля этого храма священника B. Минаева благочинный Семикаракорского благочиннического округа протоиерей Н. Овчинников: «Я помню храм в разрухе полнейшей - ни куполов, ни сводов, ни даже стен толком не было» (Воспоминания о Вознесенском храме, 2008: 2). Именно в таком состоянии церковь была передана верующим и начала реставрироваться. Особенностью реставрационного процесса, характерной для начала 1990-х гг., было отсутствие проектной документации, за исключением расчетов, составленных строительным отделом Московской Патриархии по 
личной просьбе священника и касающихся восстановления несущих конструкций для купола. К осени 1994 г. все наружные и внутренние строительные работы были закончены, стены вновь оштукатурены и побелены. Начались работы по восстановлению иконостаса. 14 мая 1995 г. митрополит Ростовский и Новочеркасский Владимир (Котляров) освятил храм и совершил в нем первое богослужение.

Публикуемый источник представляет собой рукопись, созданную в 2008 г. по просьбе настоятеля Вознесенской церкви священника В. Минаева, который собирал материалы для написания книги, посвященной истории храмов хутора Сусат (проект завершен не был). Текст рукописи написан на бумаге в клеточку формата A4 синими чернилами. В квадратных скобках публикатором приведены недостающие слова. Рукопись публикуется в соответствии с современными нормами орфографии и пунктуации.

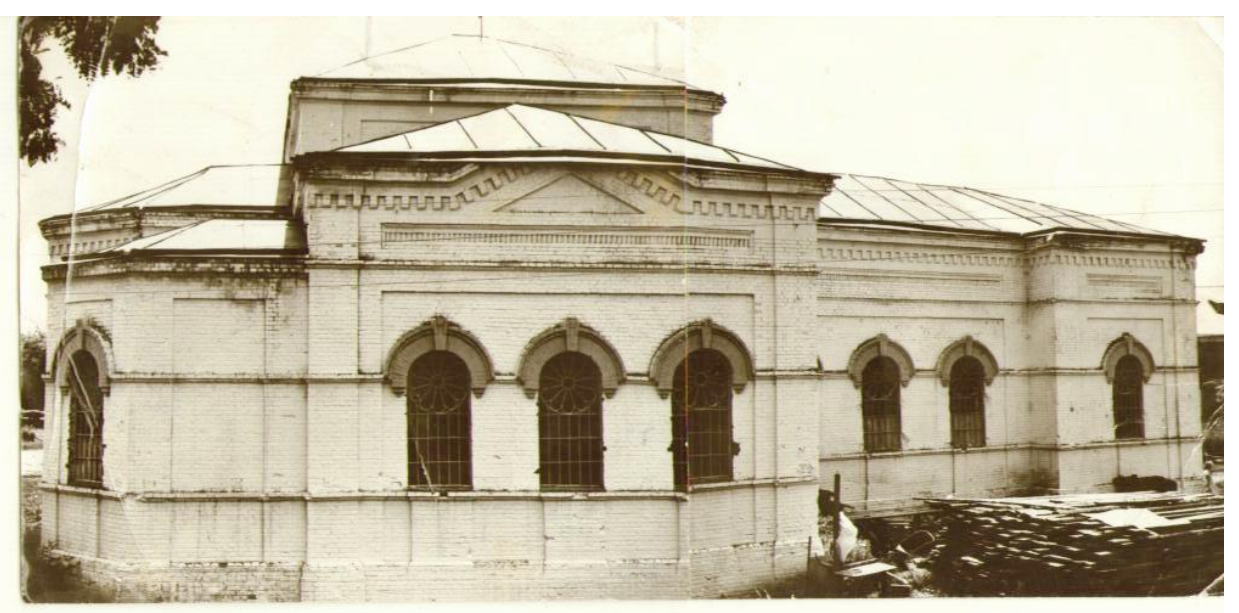

Рис. 1. Вознесенская церковь хут. Сусат на первом этапе реставрационных работ Фото из личного архива настоятеля храма священника В. Минаева

\section{Воспоминания участника восстановления Вознесенской церкви хут. Сусат. 2008 г.}

С февраля 1986 г. я начал работать директором консервного завода «Семикаракорский». Завод был одним из самых крупных заводов в Российской Федерации.

В конце марта 1990 г. мне позвонил директор сусатского совхоза Семикаракорского района Ростовской области Чеченев Виктор Григорьевич и попросил приехать в субботу к нему в гости. Какова [была] причина приглашения Виктор Григорьевич не сказал, но раз позвонил уважаемый мною директор, я принял приглашение и в рабочем графике сделал свободное время для встречи.

Приехав в субботу к конторе совхоза Сусатский, я не нашел на месте Виктора Григорьевича, но его водитель взялся меня проводить к месту встречи. Вместе с водителем я подъехал на берег реки и увидел следующую картину: на берегу горел костер, над которым висел казан с кипящей водой. Недалеко от костра сидели и о чем-то разговаривали: Зимовец Анатолий Григорьевич - первый секретарь Семикаракорского райкома партии, Павлов Петр Григорьевич - председатель Семикаракорского районного Совета депутатов, Бойчук Дмитрий Матвеевич - директор совхоза «Донские зори», Козленко Владимир Захарович директор птицефабрики «Задоно-Кагальницкая» и Яценко Александр Макарович директор совхоза «Слободской». Я поздоровался со всеми и начал осматриваться. Меня мучил вопрос - зачем позвал Виктор Григорьевич всех перечисленных лиц? Немного успокоившись, я начал осматриваться. Возле костра возился небольшого роста мужчина с седой окладистой бородой и густыми седыми волосами, а помогал ему молодой мужчина на вид 22-25 лет. Они варили уху и готовили мясо для шашлыка. Меня сильно удивило, что незнакомые люди готовят еду. Обычно это делал водитель Чеченева В.Г.

Через некоторое время Чеченев Виктор Григорьевич позвал за стол. Выпили за наступающую весну и пожелали всем здоровья. Затем Виктор Григорьевич сообщил, что он принял решение передать здание склада, стоявшего около совхозного дома культуры под 
церковь. Меня это сильно удивило - здание склада и под церковь. Как-то не вязалось в сознании предназначение здания под склад и проведение в нем церковной службы. Виктор Григорьевич рассказал всем присутствующим, что раньше в этом здании до 1929 г. была Свято-Вознесенская церковь. С 1929 г. церковь была закрыта и использовалась как сельский клуб, а когда клуб построили, то совхоз начал использовать под зернохранилище и материальный склад ${ }^{1}$. «В связи с наступлением перестройки, - сказал Виктор Григорьевич, - я принял решение передать здание под церковь». Он также сообщил, что в переданном здании 1 февраля 1990 г. состоялось первое богослужение. Затем он подозвал к столу мужчину с окладистой седой бородой и седеющей шевелюрой волос на голове и молодого юношу. Старшего была фамилия Минаев Владимир Владимирович, и он был старостой прихода, а молодой парень - Минаев Виталий Владимирович - иерей ${ }^{2}$ сусатской церкви. В ходе разговора Виктор Григорьевич сообщил, что он пригласил нас, чтобы мы поддержали начинание сусатских верующих по восстановлению храма. Свою просьбу он мотивировал тем, что в районе только одна кочетовская церковь 3 , которая находится на правом берегу р. Дон, а на левом берегу нет ни одной церкви. Не помню кто из присутствующих директоров высказался, а не будет ли это нарушением устава КПСС, и не будут ли потом разборки на бюро райкома партии? Первый секретарь Семикаракорского райкома партии Зимовец Анатолий Григорьевич поддержал начинание Чеченева Виктора Григорьевича и пообещал защиту в случае, если будут жалобы на руководителей предприятий, оказывающих помощь в восстановлении сусатской церкви.

Председатель Семикаракорского районного Совета Павлов Петр Григорьевич также поддержал начинание Чеченева Виктора Григорьевича по восстановлению церкви и пообещал защиту от налоговой инспекции и правоохранительных органов.

Затем разговор перешел в плоскость, кто чем может помочь (строительными материалами, рабочими строительных специальностей и денежными средствами). Здесь сразу директора поутихли. Директора Задоно-Кагальницкой птицефабрики и совхоза «Донские зори» пообещали по 5-7 тыс. руб. перечислить на расчетный счет. Директор совхоза «Слободской» Яценко Александр Макарович пообещал разобраться и оказать помощь строительными материалами. Я был в растерянности, понимая, что с такой помощью церковь восстановить невозможно. На вопрос, а чем поможет завод, сказал, что не готов ответить.

В следующий понедельник я пригласил к себе в кабинет заместителя директора по капитальному строительству Рубцова Евгения Ивановича и сказал, что после обеда поедем смотреть объект. Приехав в х[утор] Сусат к зданию материального склада, мы увидели обычное складское здание под скатной крышей, ничем не похожее на церковь. Я объяснил Евгению Ивановичу цель нашего приезда. Попросил прикинуть, какой объем работ надо выполнить и сколько потребуется денег. Попросили Минаева Владимира Владимировича привезти фотографию или картину общего вида церкви. Он сказал, что фотографии нет, но они поищут в архивах Ростовской епархии 4 .

Прошла неделя или две. Секретарь докладывает, что в приемной сидит какой-то мужчина с седой бородой и в кирзовых сапогах, и просится на прием. В кабинет вошел Владимир Владимирович. Скромно сел около входной двери в кабинет и молчит. Я спросил, чем [могу] помочь. Он положил на стол фотографию очень красивого трехпрестольного храма с колокольней. Посмотрев на фото сусатского храма, я понял, что мизерными 15-20 тыс. рублей, что звучали из уст директоров при первой встрече на берегу реки, храм не восстановить.

Я подписал распоряжение на отпуск строительных материалов, которые просил Минаев Владимир Владимирович, и дал распоряжение открыть заборную ведомость на отпуск строительных материалов по первому требованию представителей сусатского храма на основании доверенности.

\footnotetext{
${ }^{1}$ Сведения не верны. Вознесенская церковь хут. Сусат действовала до 1938 г.

2 Священник.

3 Успенская церковь станицы Кочетовской.

4 В архиве Ростовской и Новочеркасской епархии не хранились ни дореволюционные документы, ни фотографии.
} 
По полученной фотографии заводские сметчики прикинули объем и стоимость работ по восстановлению храма. Сумма выходила очень огромная - в пределах 400-500 тыс. руб. в ценах 1990 г.

На очередной строительной планерке, которые по пятницам проводил отдел консервной промышленности министерства сельского хозяйства Ростовской области, я поделился c начальником отдела консервной промышленности Минько Николаем Васильевичем о задаче по восстановлению сусатской церкви и попросил выделить дополнительные фонды на строительные материалы (кирпич, цемент, мраморную крошку, арматуру и профильный прокат). Николай Васильевич пообещал поговорить с министром сельского хозяйства Ростовской области в части использования прибыли, остающейся в распоряжении предприятия, на использование восстановительных работ по сусатскому храму. Мне пришлось съездить к министру агропромышленного объединения по Ростовской области и заручиться визой на заводском письме об использовании до $20 \%$ ежегодной прибыли, остающейся в распоряжении предприятия, на восстановительные работы по храму.

В начале 1991 г. завод реорганизовался в арендное предприятие «консервный завод Семикаракорский». В конце января мною было дано распоряжение о включении во внутрипостроечный титульный список завода работ по восстановлению сусатского храма в размере 150 тыс. руб. при сметной стоимости 500 тыс. руб. в ценах 1990 г. Восстановительные работы были узаконены советом завода, что ускорило восстановительные работы. Заводом был заключен договор на проведение подрядных работ с ООО «Блок», директором которого был Барминов Виктор Исаевич.

При изготовлении сводов над центральным входом и боковыми приделами для кладки центрального круглого купольного барабана потребовались инженерные расчеты и чертежи. Минаев Виталий Владимирович вместе с сусатскими казаками несколько раз ездил в проектную организацию Московской епархии, и привезли необходимую проектную документацию. Сотрудники технического отдела завода разработали чертежи сводов, а заводская ремонтная мастерская изготовила их формы. Специалисты ООО «Блок» во дворе храма установили формы, связали арматуру и заливали своды бетоном. Работа была кропотливая, и рабочие старались сделать своды гладкими. Чтобы стояли на века.

Для монтажа сводов и металлической конструкции под кладку купольного барабана завод заказывал автокраны грузоподъемностью от 60 до 70 тонн в Волгодонском предприятии «Спецтяжперевозки», которым руководил мой друг Белобровец Валерий Павлович. На монтаж каждого свода вызывали автокран из Волгодонска. Параллельно специалистами ООО «Блок» проводились работы по кладке колокольни, подкупольного барабана, работы по монтажу кровли.

Работы по приготовлению и укладке бетона на пол производили работники Строительного управления № 871, которым руководил Иванов Владимир Михайлович При строгом фондировании строительных материалов (цемент, щебень) Владимир Михайлович взял на себя ответственность и в счет перевыполнения работ по укладке бетонной дороги по территории консервного завода «Семикаракорский» в короткий срок сделал бетонное основание под мраморную крошку.

В 1994 г. завод заключил договор со специализированным отделочным участком, которым руководил Камнев Виктор Иванович, по укладке мраморной крошки. Узор и расцветку мраморной крошки разработала проектная организация Московской епархии1. Работы по изготовлению куполов были выполнены на основании договора, заключенного заводом с подрядной организацией в Волгодонске. Заготовки куполов были изготовлены в Волгодонске, перевезены в Сусат и здесь смонтированы.

Долго шла полемика по материалу, которым будут покрыты купола. Было предложение покрыть [их] оцинкованным железом, и было предложение покрыть листовой медью. Больше склонялись к покрытию листовой медью, так как она будет стоять долго и не поддается ржавлению. Фондов на листовую медь в Ростовском металлоснабсбыте не было. И тут я вспомнил своего однокурсника по институту Брынкина Виктора Ивановича. Он в то время работал председателем областного совета Карагандинской области в Казахстане. Я позвонил ему, он пообещал разобраться и попросил прислать письмо с указанием

${ }^{1}$ Вероятно, речь идет о проектной организации Московского Патриархата. 
толщины и размеров медного листа. Через некоторое время пришел счет на шесть тонн медного листа, завод его оплатил, и через две недели пришел медный лист.

Строительные работы на здании храма и внутри храма шли только в теплое время года.

Я хочу выразить свою благодарность ныне покойному Минаеву Владимиру Владимировичу. Несмотря на то, что работы по восстановлению храма были включены в титульный список завода, без его беспокойства дела бы двигались гораздо хуже. Он каждую неделю приходил на завод или домой ко мне с вопросами, которые, по его мнению, не так делаются. Небольшой пример. Встал вопрос об отделке ступеней на входе в храм и в боковые приделы храма. Договорились облицевать [их] белым мрамором. Завод завез мраморную белую плиту толщиной 20 мм. Владимир Владимирович посмотрел плиту, а затем пришел ко мне и говорит: плита очень тонкая и скоро износится под ногами прихожан. Надо мраморную плиту толщиной 40-50 мм. Такой поворот событий с толщиной плиты на ступенях тормозил сроки завершения работ. Ведь с таким трудом была приобретена мраморная белая плита (ее приобрели в Махачкале на заводе по производству мраморных плит. Но такого размера плиту там не делали). Заводские снабженцы целый месяц занимались поиском нужного размера мраморной плиты. Через месяц или больше ко мне приходит Владимир Владимирович и говорит, что мраморная плита нужной толщины и в нужном размере лежит во дворе ПМК «Мелиоводстороя», которой в то время руководил Бударин Николай Дмитриевич. Я съездил к Бударину Н.Д. и попросил помочь храму плитой за счет «Мелиоводстроя», но получил отказ. Было выставлено условие поменять мраморную плиту толщиной 5 см на равноценное количество мраморной плиты толщиной 2 см. В связи с тем, что заводские снабженцы не могли найти плиту толщиной 5 см, я дал распоряжение снабженцам провести равноценный обмен и отвезти плиту сразу в х[утор] Сусат.

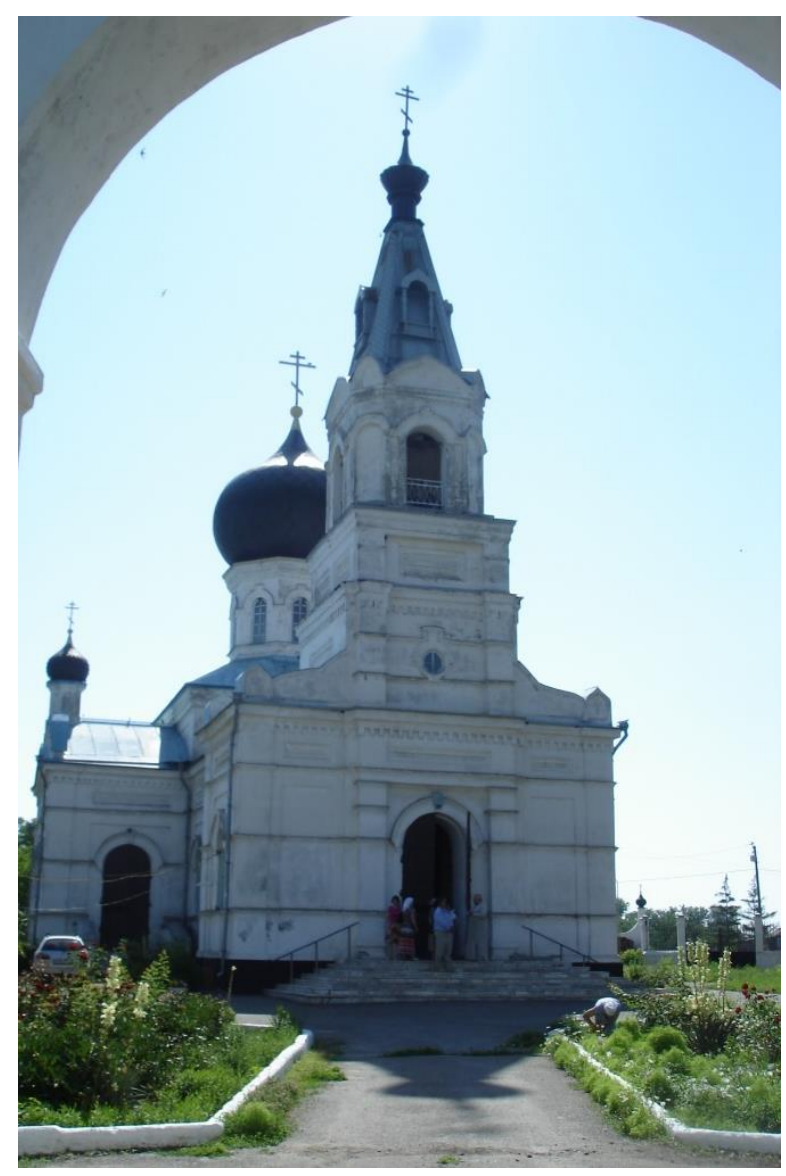

Рис. 2. Современное состояние Вознесенской церкви хутора Сусат. 2012 г. Фото А.В. Шадриной 
К осени 1994 г. все наружные и внутренние общестроительные работы были закончены. Стены снаружи и изнутри были вновь поштукатурены и побелены. Начались работы по восстановлению иконостаса. Завод уже не мог помогать в таких объемах, так как финансовое состояние завода было тяжелым.

14 мая 1995 г. митрополит Ростовский и Новочеркасский Владимир (Котляров) ${ }^{1}$ провел службу в восстановленном храме и освятил храм.

\section{Благодарности}

Публикация подготовлена в рамках реализации ГЗ ЮНЦ РАН, № гр. проекта AАААA20-120122990111-9.

\section{Литература}

Воспоминания о Вознесенском храме, 2008 - Воспоминания о Вознесенском храме хутора Сусат протоиерея Николая Овчинникова. Рукопись, 2008. 3 с.

ГАРО - Государственный архив Ростовской области

Кравченко и др., 2020 - Кравченко Н.В., Маврикий (Звягинцев), иером., Федорова H.B., Андрющенко A.A. История храма Лакедемоновка. Ростов-на-Дону: Донской издательский дом, 2020. 116 с.

Молчанова, Макаренко, 2020 - Молчанова B.A., Макаренко В.О. Хранимый верой: история Свято-Николаевского храма села Николаевка Неклиновского района Ростовской области. Ростов-на-Дону: [Б.и.], 2020. 144 с.

Табунщикова, Шадрина, 2013 - Табунщикова Л.В., Шадрина А.В. Закрытие церквей и молитвенных зданий Донской области в 1920-е-1930-е гг. Сб. документов. Ростов-на-Дону: [Б.и.], 2013. 504 с.

Шадрина, 2012 - Шадрина А.В. Летопись церквей города Константиновска. Ростов-наДону: Изд-во ЮНЦ РАН, 2012. 402 с.

Шадрина, 2021 - Шадрина А.В. Ростовский кафедральный собор Рождества Пресвятой Богородицы. История. Ростов-на-Дону: Изд-во ЮНЦ РАН, 2021. 400 с.

\section{References}

GARO - Gosudarstvennyy arkhiv Rostovskoy oblasti [State Archives of the Rostov Region]

Kravchenko i dr., 2020 - Kravchenko, N.V., Mavrikiy (Zvyagintsev), hieromonk, Fedorova, N.V., Andryushchenko, A.A. (2020). Istoriya khrama Lakedemonovka [The history of the Lacedaemonovka temple]. Rostov-on-Don: Donskoy izdatel'skiy dom, 116 p. [in Russian]

Molchanova, Makarenko, 2020 - Molchanova, V.A., Makarenko, V.O. (2020). Khranimyy veroy: istoriya Svyato-Nikolayevskogo khrama sela Nikolayevka Neklinovskogo rayona Rostovskoy oblasti [Guarded by faith: the history of the St. Nicholas Church in the village of Nikolaevka in the Neklinovsky District of the Rostov Region]. Rostov-on-Don: [a.m.], 144 p. [in Russian]

Shadrina, 2012 - Shadrina, A.V. (2012). Letopis' tserkvey goroda Konstantinovska (2012) [Chronicle of the churches of the city of Konstantinovsk]. Rostov-on-Don: SSC RAS Publishers, 402 p. [in Russian]

Shadrina, 2021 - Shadrina, A.V. (2021). Rostovskiy kafedral'nyy sobor Rozhdestva Presvyatoy Bogoroditsy. Istoriya (2021) [Rostov Cathedral of the Nativity of the Blessed Virgin Mary. History]. Rostov-on-Don: SSC RAS Publishers, 400 p. [in Russian]

Tabunshchikova, Shadrina, 2013 - Tabunshchikova, L.V., Shadrina, A.V. (2013). Zakrytiye tserkvey i molitvennykh zdaniy Donskoy oblasti v 1920-ye-1930-ye gg. [Closure of churches and prayer buildings in the Don region in the 1920s - 1930s]. Collection of documents. Rostov-on-Don: [without publishing house], 504 p. [in Russian]

Vospominaniya o Voznesenskom khrame, 2008 - Vospominaniya o Voznesenskom khrame khutora Susat protoiyereya Nikolaya Ovchinnikova [Memories of the Ascension Church of the Khutor Susat by Archpriest Nikolai Ovchinnikov]. Manuscript, 2008. 3 p. [in Russian]

\footnotetext{
1 Митрополит Владимир (Котляров) возглавлял Ростовскую и Новочеркасскую епархию с 1993, по 1995 г.
} 


\section{Воспоминания участника восстановления Вознесенской церкви хутора Сусат Ростовской области в 1980-х гг.}

Подготовка к публикации, вступительная статья и комментарии

Алла В. Шадрина ${ }^{\text {a, * }}$

a Федеральный исследовательский центр Южный научный центр Российской академии наук, Российская Федерация

Аннотация. Одним из наименее исследованных аспектов жизни общества позднего советского и первых лет постсоветского периодов является время так называемого «религиозного ренессанса», который характеризовался как повышенным интересом к религии и Русской православной церкви, так и возвращением в повседневность россиян храмов. Передача верующим полуразрушенных церквей стала причиной начала часто длительных по времени реставрационных процессов. Публикуемый документ, представляющий собой воспоминания участника восстановления церкви в хуторе Сусат Семикаракорского района Ростовской области, дает представление об уникальном и не имеющем аналогов на юге России случаев восстановления церкви с помощью чиновников местных органов власти и крупных предприятий Семикаракорского района Ростовской области. Публикуемый источник представляет собой рукопись, созданную в 2008 г. по просьбе настоятеля Вознесенской церкви священника В. Минаева, который собирал материалы для написания книги, посвященной истории храмов хутора Сусат.

Ключевые слова: автокоммуникативный источник, поздний советский период, Ростовская область, хутор Сусат, воссоздание церкви.

* Корреспондирующий автор

Адрес электронной почты: shadrina@ssc-ras.ru (А.В. Шадрина) 